\title{
RESEARCH
}

Open Access

\section{TCONS_00230836 silencing restores stearic acid-induced $\beta$ cell dysfunction through alleviating endoplasmic reticulum stress rather than apoptosis}

Rui Guo ${ }^{1}$, Yunjin Zhang ${ }^{1}$, Yue Yu', Shenghan Su${ }^{1 \dagger}$, Qingrui Zhao ${ }^{1 \dagger}$, Xia Chu', Shenglong Li ${ }^{2^{*}}$, Huimin Lu凶 ${ }^{1 *}$ (D) and Changhao Sun ${ }^{1 *}$

\begin{abstract}
Background: Chronic exposure of pancreatic $\beta$ cells to high levels of stearic acid (C18:0) leads to impaired insulin secretion, which accelerates the progression of type 2 diabetes mellitus (T2DM). Recently, long noncoding RNAs (IncRNAs) were found to participate in saturated fatty acid-induced metabolism dysfunction. However, their contribution to stearic acid-induced $\beta$-cell dysfunction remains largely unknown. This study evaluated the possible role of the IncRNA TCONS_00230836 in stearic acid-stimulated lipotoxicity to $\beta$ cells.
\end{abstract}

Method: Using high-throughput RNA-sequencing, TCONS_00230836 was screened out as being exclusively differentially expressed in stearic acid-treated mouse $\beta$-TC 6 cells. Co-expression network was constructed to reveal the potential mRNAs targeted for IncRNA TCONS_00230836. Changes in this IncRNA's and candidate mRNAs' levels were further assessed by real-time PCR in stearic acid-treated $\beta$-TC6 cells and islets of mice fed a high-stearic-acid diet (HSD). The localization of TCONS_00230836 was detected by fluorescent in situ hybridization. The endogenous IncRNA TCONS_00230836 in $\beta$-TC6 cells was abrogated by its Smart Silencer.

Results: TCONS_00230836 was enriched in mouse islets and mainly localized in the cytoplasm. Its expression was significantly increased in stearic acid-treated $\beta$-TC6 cells and HSD-fed mouse islets. Knockdown of TCONS_00230836 significantly restored stearic acid-impaired glucose-stimulated insulin secretion through alleviating endoplasmic reticulum stress. However, stearic acid-induced $\beta$ cell apoptosis was not obviously recovered.

Conclusion: Our findings suggest the involvement of TCONS_00230836 in stearic acid-induced $\beta$-cell dysfunction, which provides novel insight into stearic acid-induced lipotoxicity to $\beta$ cells. Anti-IncRNA TCONS_00230836 might be a new therapeutic strategy for alleviating stearic acid-induced $\beta$-cell dysfunction in the progression of T2DM.

Keywords: Stearic acid, Pancreatic $\beta$ cell, LncRNA, Endoplasmic reticulum stress

\footnotetext{
*Correspondence: Ihm_519@sina.com; changhaosun2002@163.com; Lishenglong_1982@163.com

'Shenghan Su and Qingrui Zhao contributed equally to this work.

${ }^{2}$ General Surgery Department, The Second Affiliated Hospital of Harbin

Medical University, Harbin, China

'Department of Nutrition and Food Hygiene (National Key Discipline), Public

Health College, Harbin Medical University, HarbinHei Longjiang province,

150081, People's Republic of China
}

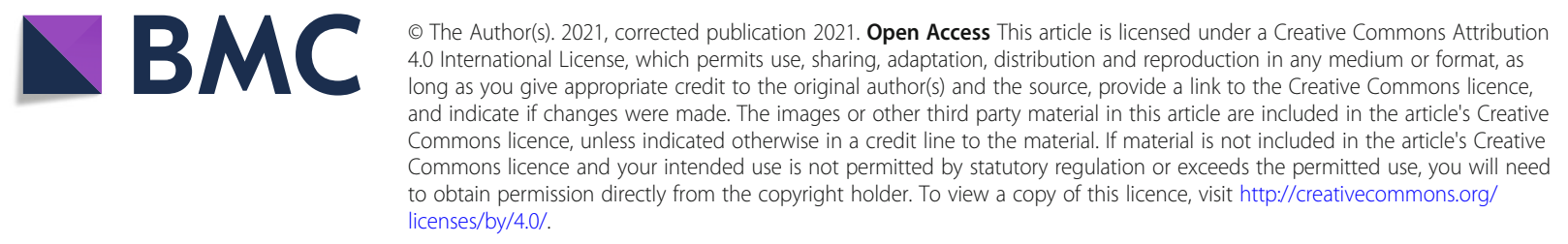




\section{Introduction}

Chronic exposure to elevated saturated fatty acids (SFAs) of pancreatic $\beta$ cells is a key trigger of impaired insulin secretion, which is one of the most important characteristics of type 2 diabetes mellitus (T2DM). Evidence accumulated to date has indicated that palmitic acid-mediated insulin resistance and $\beta$ cell dysfunction are closely related to T2D M[1-3]. However, little attention has been paid to stearic acid-induced worsening of $\beta$ cell function. In our previous studies and other research, it has been demonstrated that, whether in the postprandial serum of T2DM patients or in the fasting serum of high-fat-diet-fed mice [4-7], only stearic acid levels were profoundly increased. Meanwhile, a longterm high level of stearic acid exhibited a stronger destructive effect on $\beta$ cells than that of palmitic acid [5, 8]. Although endoplasmic reticulum (ER) stress [5, 9] and apoptosis $[8,10]$ are accepted as major contributors to stearic acid-induced $\beta$ cell dysfunction, the molecular mechanisms involved in this remain largely unclear.

Long noncoding RNAs (lncRNAs) [11], generally defined as RNA molecules >200 nucleotides in length without evident protein-coding capacity, are well known to be involved in diverse gene-regulatory mechanisms such as transcription, imprinting, splicing, protein degradation, and epigenetic marks on chromatin [12, 13], and their dysregulation has been implicated in many diseases, especially in several metabolic diseases [14, 15]. Recently, a number of IncRNAs have been reported to participate in SFA-induced metabolic dysfunction in liver [16], adipocytes [17, 18], skeletal muscle cells [19], and pancreatic $\beta$ cells $[20,21]$. However, there are no data regarding the possible contribution of IncRNAs to stearic acid-induced $\beta$ cell dysfunction.

Using RNA-sequencing and qRT-PCR, we showed for the first time that the IncRNA TCONS_00230836 was differentially expressed exclusively in stearic acid-treated $\beta$-TC6 cells, compared with both palmitic acid-treated cellsand control cells. We investigated the effect of the lncRNA TCONS_00230836 on stearic acid-induced $\beta$ cell dysfunction by loss-of-function approaches in a cellular model of lipotoxicity. Our experimental results suggested that this IncRNA is a detrimental factor to pancreatic $\beta$ cells in the presence of stearic acid and that its knockdown could mitigate stearic acid-stimulated impairment of insulin secretion, which would provide a potential target for the prevention and treatment of T2DM.

\section{Material and methods}

\section{Chemicals}

Stock solutions of stearic acid and palmitic acid (Sigma, St. Louis, MO, USA) supplemented with BSA ( $3 \mathrm{mmol} / \mathrm{L}$ fatty acids: $1.5 \mathrm{mmol} / \mathrm{L} \mathrm{BSA}$ ) were prepared by dissolving them in ethanol and saponifying them with sodium hydroxide, as described previously [22]. After the sodium salt had dried, it was resuspended in saline and then heated at $80{ }^{\circ} \mathrm{C}$ until completely dissolved. Next, $20 \%$ (w/v) BSA was added and the mixture was stirred at 50 ${ }^{\circ} \mathrm{C}$ for $4 \mathrm{~h}$. The complex was then sterilized and aliquoted.

\section{Cell culture}

The pancreatic $\beta$-TC6 cells was obtained from the Shanghai Academy of Chinese Sciences Cell Library and cultured in Dulbecco's modified Eagle's medium (DMEM; Gibco/Life Technologies, Carlsbad, CA, USA), supplemented with $15 \%$ fetal bovine serum (FBS; Gibco/ Life Technologies), $50 \mu \mathrm{g} / \mathrm{mL}$ streptomycin, $50 \mathrm{IU} / \mathrm{mL}$ penicillin (Gibco/Life Technologies), and $1.5 \mathrm{~g} / \mathrm{L}$ $\mathrm{NaHCO}_{3}$. Mouse islets were isolated after collagenase P (Cat. 11213873001; Roche Molecular Biochemicals, Germany) digestion of the pancreas by ductal injection and filtered with hardware cloth $(600 \mu \mathrm{m})$. Next, islets were purified with different concentrations of Ficoll 400 (Cat. 17-0300-10; Pharmacia). Finally, islets were incubated in RPMI 1640 (Gibco) containing 10\% FBS, 0.11 $\mathrm{g} / \mathrm{L}$ sodium pyruvate, and 100 units $/ \mathrm{mL}$ penicillinstreptomycin. The $\beta$-TC6 cells and islets were incubated with $400 \mu \mathrm{mol} / \mathrm{L}$ stearic or palmitic acid for $24 \mathrm{~h}$.

\section{RNA sequencing and data analysis}

The lncRNA and mRNA high-throughput sequencing was performed by Genewiz (Suzhou, China), processing nine samples from pancreatic $\beta$-TC6 cells (3 control, 3 stearic acid, and 3 palmitic acid samples). Differential expression analysis was performed using the DESeq Bioconductor package in $\mathrm{R}$ by first transforming the raw count data to $\log _{2}$ counts per million reads using the "voom" function $(P<0.05)$.

\section{Construction of gene co-expression network}

The Pearson correlation coefficients (PCC) were performed for lncRNA TCONS_00230836-mRNA pairs, of which the $\mathrm{PCC} \geq 0.950$, or $\mathrm{PCC} \leq-0.950, P<0.05$ were selected to construct the gene co-expression network using Cytoscape software. Each gene corresponds to a node in the network.

\section{Animal experiments}

Twenty male C57BL/6J mice (6 weeks old) were purchased from the Beijing Vital River Laboratory Animal Technology Company (Beijing, China). After adaptive feeding for 1 week, these mice were randomly divided into control and high-stearic-acid diet groups $(n=10$ per group), according to their body weights. The control diet (1025) and high-stearic-acid diet (HSD) (H10060) were obtained from Beijing HFK Bioscience Co., Ltd. 
(Beijing, China) (Additional file 1). After 20 weeks of feeding the mice, islets and blood samples were collected for biochemical analysis. Fasting (12 h) serum glucose, total cholesterol, triacylglycerol, high-density-lipoprotein cholesterol, and low-density-lipoprotein cholesterol levels were calculated using an automatic analyzer (Hitachi-7100; Hitachi, Tokyo, Japan), kits for which were purchased from Biosino Biotechnology, Co. (Beijing, China). Serum insulin level was measured using a mouse/rat insulin ELISA kit (Linco Research, St. Charles, MO, USA).

\section{Serum nonesterified fatty acid profile measurement}

Fasting serum nonesterified fatty acids were transformed to fatty acid methyl esters, as described in our previous studies [7, 23]. Gas chromatography-mass spectrometry analysis was performed using a TRACE gas chromatograph with a Polaris Q mass spectrometer (Thermo Finnigan, San Jose, CA, USA). Separation was obtained on a J\&W DB-WAX capillary column (30-m, 0.25-mm I.D., $0.25-\mu \mathrm{m}$ film thickness; Agilent J\&W Scientific, Folsom, CA, USA). Heptadecanoic acid (C17:0) was used as an internal standard.

\section{Cell viability measurements}

Cell viability was measured by the assessment of lactate dehydrogenase (LDH) release and CCK 8 assay. For measuring $\mathrm{LDH}$, the culture medium was collected and characterized using LDH assay kit (Thermo Fisher Scientific Inc.). For the CCK 8 assay, we used the Cell Counting Kit 8 (CCK-8, C0038; Beyotime Biotechnology, Shanghai, China). The $\beta$-TC6 cells were seeded into each well of a 96 -well plate and $100 \mu \mathrm{L}$ of CCK-8 mixed reagents were added to each well. After $1 \mathrm{~h}$ of incubation at $37{ }^{\circ} \mathrm{C}$, absorbance was determined at $450 \mathrm{~nm}$ using a microplate reader (SpectraMax M2; Molecular Devices, San Jose, CA, USA).

\section{Apoptosis assay}

The $\beta$-TC6 cells were collected and stained with fluorescein isothiocyanate (FITC)-annexin $\mathrm{V}$ and propidium iodide (PI), in accordance with the manufacturer's instructions (Lot\#AB116F; Absin, Shanghai, China). The apoptosis rate was analyzed by flow cytometry (LSR Fortessa; BD Biosciences, San Jose, CA, USA).

\section{Fluorescent in situ hybridization (FISH)}

The $\beta$-TC6 cells were seeded into a 24-well plate with sterile slides overnight. Cells were rinsed using $1 \times$ PBS for $5 \mathrm{~min}$ and fixed in $4 \%$ formaldehyde at room temperature for $10 \mathrm{~min}$. The $\beta$-TC6 cells were washed three times with $1 \times$ PBS for 5 min each. Next, the cells were permeabilized in $1 \times$ PBS containing $0.5 \%$ Triton X100 for $5 \mathrm{~min}$ at $4{ }^{\circ} \mathrm{C}$. After washing the cells with $1 \times$
PBS, they were blocked in Blocking Solution and Prehybridization (1:99) mixed solution at $37{ }^{\circ} \mathrm{C}$ for half an hour. Then, in the dark, discarding the mixed solution, the $\beta$-TC6 cells were incubated with a hybridized mixture containing lncRNA Probe Mix or U6/18S at $37{ }^{\circ} \mathrm{C}$ overnight. On the second day, the $\beta$-TC6 cells were washed at $42{ }^{\circ} \mathrm{C}$ with different concentrations of SSC solution, which were also protected from the light. After immersing the $\beta$-TC6 cells in $1 \times$ PBS for 5 min, they were stained with DAPI staining solution at room temperature for $10 \mathrm{~min}$ and then washed with $1 \times$ PBS. The slides taken from the 24-well plate were observed with a laser confocal microscope. The whole process was protected from light to prevent quenching. The locked nucleic acid-modified oligonucleotide probe targeting lncRNA TCONS_00230836 and the FISH Kit were purchased from Ribobio Co., Ltd. (Guangzhou, China).

\section{Transfection procedures}

$\beta$-TC6 cells were transfected with Smart Silencer for TCONS_00230836 and its negative control (Ribobio Co. Ltd.) using C10511-05 riboFect ${ }^{\mathrm{Tu}} \mathrm{CP}$ Transfection Kit (Ribobio Co., Ltd.)for $6 \mathrm{~h}$, in accordance with the manufacturer's instructions, prior to incubating in normal culture medium for $24 \mathrm{~h}$. Then, discarding the supernatant, $\beta$-TC6 cells were treated with stearic acid for another 24 h. The sequences of IncRNA Smart Silencer for mouse TCONS_00230836 are displayed in Table 1, including three siRNA and three antisense oligonucleotides.

\section{Quantitative real-time polymerase chain reaction (qRT- PCR)}

Total RNA was extracted from $\beta$-TC6 cells and mouse islets using TRIzol reagent (Invitrogen), in accordance with the manufacturer's protocol. The qRT-PCR was performed with SYBR Green PCR Master Mix (Applied Biosystems, Foster City, CA, USA), with $\beta$-actin as an internal control. All primers used in this study were synthesized by Sangon Biotech Co., Ltd. (Shanghai, China), the sequences of which are listed in Table 2.

\section{Western blotting}

Cells were gently washed three times in $1 \times$ PBS and then $50 \mu \mathrm{L}$ of intermediate RIPA Lysis Buffer (Beyotime) was added per 24-well plate. Protein concentrations were detected using bicinchoninic acid (BCA) protein assay kits (Cat. No. P0010; Beyotime). Protein samples (approximately $80 \mu \mathrm{g}$ ) were separated by sodium dodecyl sulfate polyacrylamide gel electrophoresis and transferred to polyvinylidene fluoride membranes. The primary antibodies used were as follows: Phospho-PERK (3179S, CST, dilution of 1:1000), PERK (3192, CST, dilution of 1:1000), Phospho-eIF2 $\alpha$ (9721, CST, dilution of 1:1000), eIF2 $\alpha$ (9722, CST, dilution of 1:1000), Caspase-3 (9662, 
Table 1 The sequences of IncRNA Smart Silencer for mouse TCONS_00230836

\begin{tabular}{ll}
\hline Gene & Sequences \\
\hline siRNA-1 target sequence & CCTTAATCCCAACCCTCAA \\
siRNA-2 target sequence & TAGACATAGCCACATGAAA \\
siRNA-3 target sequence & CCCAATAGTTAATGACAGA \\
Antisense oligonucleotides target sequence-1 & GCTGTCAAAAAGGAATCACA \\
Antisense oligonucleotides target sequence-2 & GGAAATGCAGTGTAGTAGAA \\
Antisense oligonucleotides target sequence-3 & ATGGGCCCACCCTCTAAGAT \\
\hline
\end{tabular}

CST, dilution of 1:1000), Parp-1 (9532, CST, dilution of $1: 1000)$, Bcl-2 (4223, CST, dilution of 1:1000), ATF-6 (65880, CST, dilution of 1:1000), IRE1 $\alpha$ (3294, CST, dilution of 1:1000), and $\beta$-actin (sc-130657, Santa Cruz, dilution of 1:800). The secondary antibody was anti-rabbit (s3738, Promega, dilution of 1:7500) alkaline phosphatase-conjugated antibody. Protein coloration was performed using the Stabilized Substrate for Alkaline Phosphatase (S3841, Promega) and was screened by the FluorChem R system (ProteinSimple, San Jose, CA, USA).

Table 2 Primer sequences used for qRT-PCR

\begin{tabular}{|c|c|c|}
\hline Gene & & sequences ( $5^{\prime}$ to $\left.3^{\prime}\right)$ \\
\hline \multirow[t]{2}{*}{ TCONS_00230836 } & Forward & AACCACAGGCTTCGGGATAGTC \\
\hline & Reverse & CAAGCATAACAGGCGGGAAGTC \\
\hline \multirow[t]{2}{*}{ ENSMUST00000074898 } & Forward & ACCTTAAACGACGAGAAGCAATGG \\
\hline & Reverse & AGCCAGACACGTAGCCCACACG \\
\hline \multirow[t]{2}{*}{ ENSMUST00000086399 } & Forward & TGGTCACCGTTGTGATCCC \\
\hline & Reverse & TGAGGTCCTCCTTGCATG \\
\hline \multirow[t]{2}{*}{ ENSMUST00000050785 } & Forward & CTGTCTGTCTGCCACTCCAT \\
\hline & Reverse & GCTGGCCAAATAAGAAGAGG \\
\hline \multirow[t]{2}{*}{ ENSMUST00000124100 } & Forward & ACAAACCGCAGAGAAACAAA \\
\hline & Reverse & CCTCCCTCTGCCCTAGTATG \\
\hline \multirow[t]{2}{*}{ ENSMUST00000092822 } & Forward & GCAGACCCAGTCGTTGTAC \\
\hline & Reverse & AAGCCTGTGGCACAACATC \\
\hline \multirow[t]{2}{*}{ ENSMUST00000021620 } & Forward & GGCTGAAGACAGTTGTGGAA \\
\hline & Reverse & GGGTAAATCTTGCCCTTTCA \\
\hline \multirow[t]{2}{*}{ ENSMUST00000073388 } & Forward & GAGTCACTTGTCCGCAGCTGTC \\
\hline & Reverse & TCGCTGTCAGTTAAGTCCAGG \\
\hline \multirow[t]{2}{*}{ ENSMUST00000159720 } & Forward & CGCTATTGTCTTCTTGATGGAC \\
\hline & Reverse & CTTCAACAGTTTCCCTGAGTTG \\
\hline \multirow[t]{2}{*}{ ENSMUST00000131456 } & Forward & TGATGAGTAGCGTAAAGTACCC \\
\hline & Reverse & ATATGAGGCATCGTCAGGTAAG \\
\hline \multirow[t]{2}{*}{ ENSMUST00000185596 } & Forward & ATCTCTITGCCTTCCTCAATCA \\
\hline & Reverse & GTITGATCAGCTCATTCACGT \\
\hline \multirow[t]{2}{*}{$\beta$-actin } & Forward & GGTCAGAAGGACTCCTATGTGG \\
\hline & Reverse & TGTCGTCCCAGTTGGTAACA \\
\hline
\end{tabular}

\section{Glucose-stimulated insulin secretion assay}

To assess glucose-stimulated insulin secretion (GSIS), $\beta$ TC6 cells were incubated in secretion buffer $[\mathrm{NaCl} 129$, $\mathrm{KCl} 4.8, \mathrm{MgSO}_{4} 1.2, \mathrm{KH}_{2} \mathrm{PO}_{4} 1.2, \mathrm{CaCl}_{2} 2.5, \mathrm{NaHCO}_{3}$ 5.0, and HEPES 10 (all $\mathrm{mmol} / \mathrm{L}$ ) supplemented with 1 $\mathrm{mg} / \mathrm{mL}$ bovine serum albumin, adjusted to $\mathrm{pH}$ 7.4] for an additional $60 \mathrm{~min}$ with 2.8 or $20 \mathrm{mmol} / \mathrm{L}$ glucose [5]. After collecting the supernatant for insulin measurement, the $\beta$-TC6 cells were lysed in intermediate RIPA Lysis Buffer (Beyotime) for later evaluation of the total protein content with BCA protein assay reagent kit (Cat. No. P0010, Beyotime) following the manual. Insulin levels in cell culture medium and $\beta$-TC6 cells were measured using a mouse/rat insulin ELISA kit (Linco Research) and standardized by every milligram protein per hour in each well.

\section{Statistics}

All statistical data were analyzed with SPSS software, version 21.0 (SPSS Inc., Chicago, IL, USA), and are reported as mean \pm SEM. Two-tailed Student's $t$ test was used to analyze differences between two groups, and one-way ANOVA followed by Student-Newman-Keuls test was used to test differences among three or more groups. $P$ values $<0.05$ were considered statistically significant.

\section{Results}

\section{Animal model characteristics}

We successfully established a mouse model to mimic the increased proportions of stearic acid in vivo, as shown by a significant increase in circulating stearic acid in HSD-fed mice (Additional file 2). The metabolic characteristics of these animals are displayed in Additional file 3.

\section{Upregulation of IncRNA TCONS_00230836 expression in stearic acid-treated $\beta$-TC6 cells and islets of mice fed a high-stearic-acid diet.}

The results obtained by high-throughput RNAsequencing demonstrated that the IncRNA TCONS 00230836, an intergenic lncRNA located at 65803111 to 65809116 of chromosome 10, was markedly elevated with a $1.328 \log _{2}$ fold change ( $P$ value: $\left.5.062 \mathrm{E}-07\right)$ in $\beta$ TC6 cells exposed to stearic acid and a $0.270 \log _{2}$ fold 
change ( $P$ value: 0.327$)$ in the palmitic acid-treated cells, compared with the level in control cells (Fig. 1a). A similar increase in lncRNA TCONS_00230836 level was also revealed in both stearic acid-treated $\beta$-TC6 cells and islets of mice fed a high-stearic-acid diet by qRT-PCR. The expression level of the lncRNA TCONS_00230836 was increased by 3.744 -fold in stearic acid-treated $\beta$ TC6 cells (Fig. 1b) and 5.115-fold in the islets of mice from the high-stearic-acid group (Fig. 1c), compared with that in the corresponding controls.

\section{Differential expression of IncRNA TCONS_00230836 in mice various tissues}

The selected tissues are closely related to high-fat-diet induced metabolic disorders. Among them, the expression of lncRNA TCONS_00230836 was highest in the islets and lowest in the skeletal muscle of HSDfed mice (Fig. 2). However, no matching sequence was detected in peritesticular and perirenal adipose tissues (data not shown). In addition to islets, after the treatment with a high concentration of stearic acid, the lncRNA TCONS_00230836 level was also increased in brown adipose, whereas it was decreased in the liver and skeletal muscle of HSD-fed mice (Additional file 4).
IncRNA TCONS_00230836 is mainly localized in cytoplasm The confocal images of FISH showed that the lncRNA TCONS_00230836 is mainly distributed in the cytoplasm of $\beta$-TC6 cells (Fig. 3).

\section{Knockdown of IncRNA TCONS_00230836 reversed stearic acid-induced impaired insulin secretion in islets and $\beta$ - TC6 cells}

Both in islets and $\beta$-TC6 cells (Fig. 4a, b), transfection of the IncRNA TCONS_00230836 Smart Silencer for $24 \mathrm{~h}$ efficiently reduced the stearic acid-increased intracellular lncRNA TCONS_00230836 levels. Meanwhile, similar results were consistently observed in $\beta$ TC6 cells as indicated by FISH (Fig. 4c). Then, as shown in Fig. 4d, e, stearic acid markedly decreased GSIS in islets and $\beta$-TC6 cells, separately. After transfection of the lncRNA TCONS_00230836 Smart Silencer into pancreatic islets and $\beta$-TC6 cells, stearic acid-induced GSIS impairment was significantly alleviated. However, no significant alteration was observed in GSIS when the IncRNA TCONS_00230836 Smart Silencer was transfected alone in the absence of stearic acid. Additionally, the insulin content in $\beta$-TC6 cells were not significantly changed after transfection of TCONS_00230836 Smart Silencer in the presence or absence of stearic acid. (Additional file 5).

A

\begin{tabular}{ccccc}
\hline IncRNA & & $\begin{array}{c}\log _{2} \text { Fold } \\
\text { change }\end{array}$ & P value & Genomic location \\
\hline TCONS- & SA & 1.328 & $5.06 \mathrm{E}-07$ & $\begin{array}{c}\text { chr7:65803111- } \\
65809116\end{array}$ \\
\cline { 2 - 4 } 00230836 & $\mathrm{PA}$ & 0.270 & 0.327 & \\
\hline
\end{tabular}

B

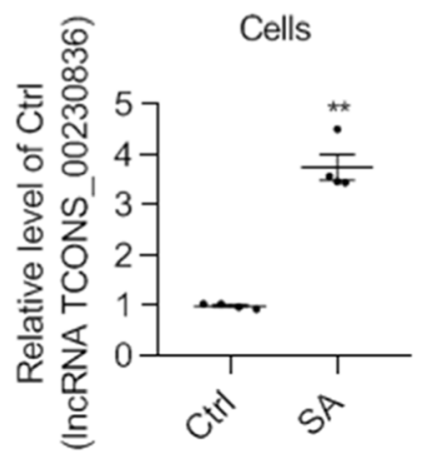

C

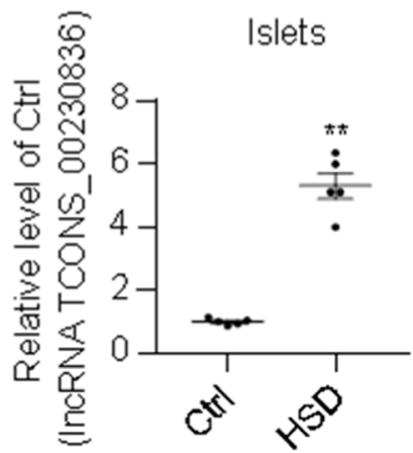

Fig. 1 LnCRNA TCONS_00230836 upregulation in stearic acid-treated $\beta$-TC6 cells and islets of mice fed a high-stearic-acid diet. a The studied IncRNA TCONS_00230836 with fold changes, $p$ values, and genomic locations in the presence of stearic acid and palmitic acid by RNA sequencing, respectively. ( $n=3$ per group) b qRT-PCR results verified that the level of the IncRNA TCONS_00230836 was elevated in stearic acid-treated $\beta$-TC6 cells. $(n=4)$ c The expression of the IncRNA TCONS_00230836 was also increased in the islets $(n=5)$ from mice fed a high-stearic-acid diet, as revealed by qRT-PCR. Ctrl control group, SA stearic acid, PA palmitic acid, HSD high-stearic-acid diet. ${ }^{* *} p<0.01$, versus the Ctrl group 


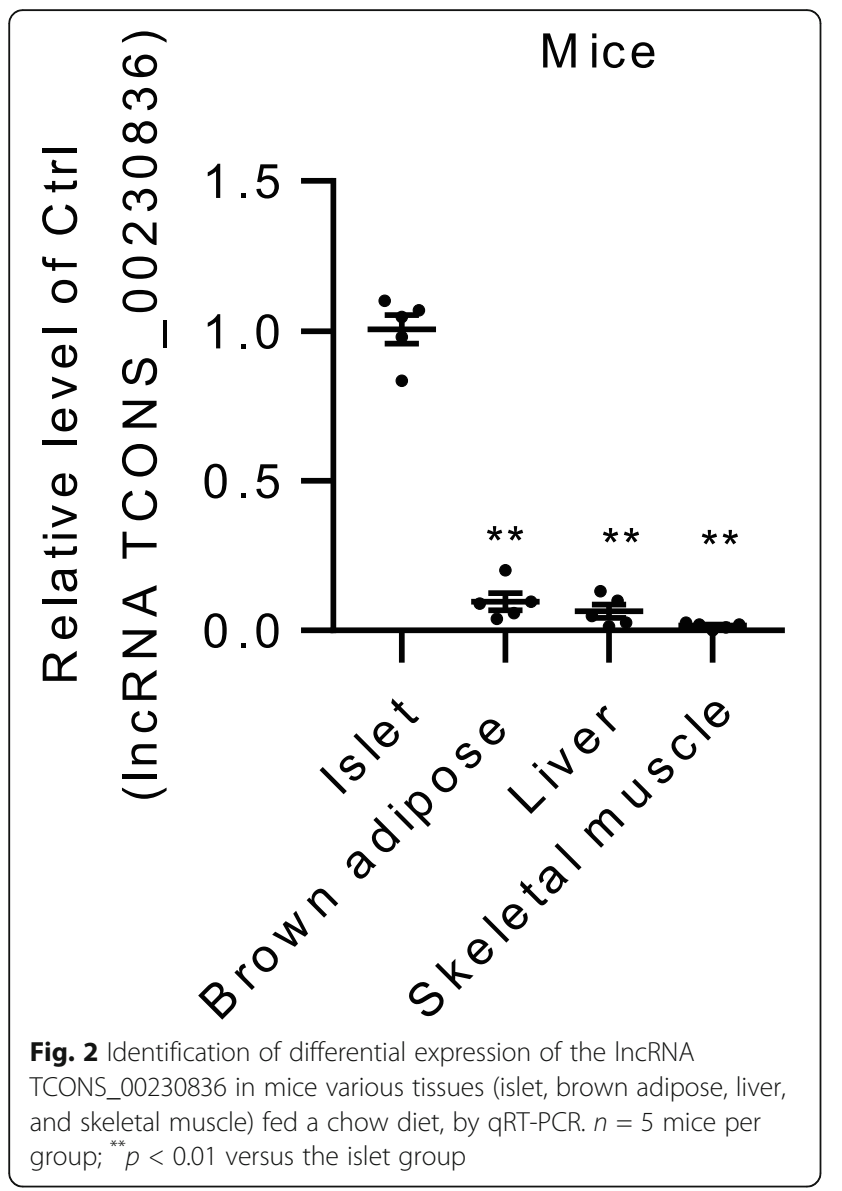

Inhibition of IncRNA TCONS_00230836 alleviated stearic acid-induced ER stress rather than apoptosis in $\beta$-TC6 cells and mice islets

Stearic acid apparently suppressed the cell survival rate and induced cell death in $\beta$-TC6 cells. Silencing the lncRNA TCONS_00230836 did not significantly block the stearic acid-stimulated cell viability reduction (Fig. 5a) and cell death (Fig. 5b). Meanwhile, the annexin V-FITC apoptosis assay results showed that IncRNA TCONS_00230836 inhibition did not reduce the stearic acid-increased percentage of apoptotic cells (Fig. 5c). Besides, the elevated protein levels of cleaved-Parp1 and cleavedCaspase3, and the decreased levels of B-cell CLL/ lymphoma 2 in the stearic acid group were not rescued by the IncRNA TCONS_00230836 Smart Silencer (Fig. 5d). However, the expression of the ER stress-related proteins Phospho-PERK and PhosphoeIF $2 \alpha$ in stearic acid-treated $\beta$-TC6 cells was significantly decreased after inhibition of the lncRNA TCONS_00230836 (Fig. 6a), whereas stearic acidincreased protein levels of ATF-6 and IRE1 $\alpha$ were not suppressed after knockdown of TCONS 00230836 (Fig. 6b). Moreover, transfection of the lncRNA TCONS_00230836 Smart Silencer alone did not alter apoptosis and ER stress in $\beta$-TC6 cells. In addition, similar results were consistently observed in mice islets (Fig 7a-c, Fig. 8a, b).

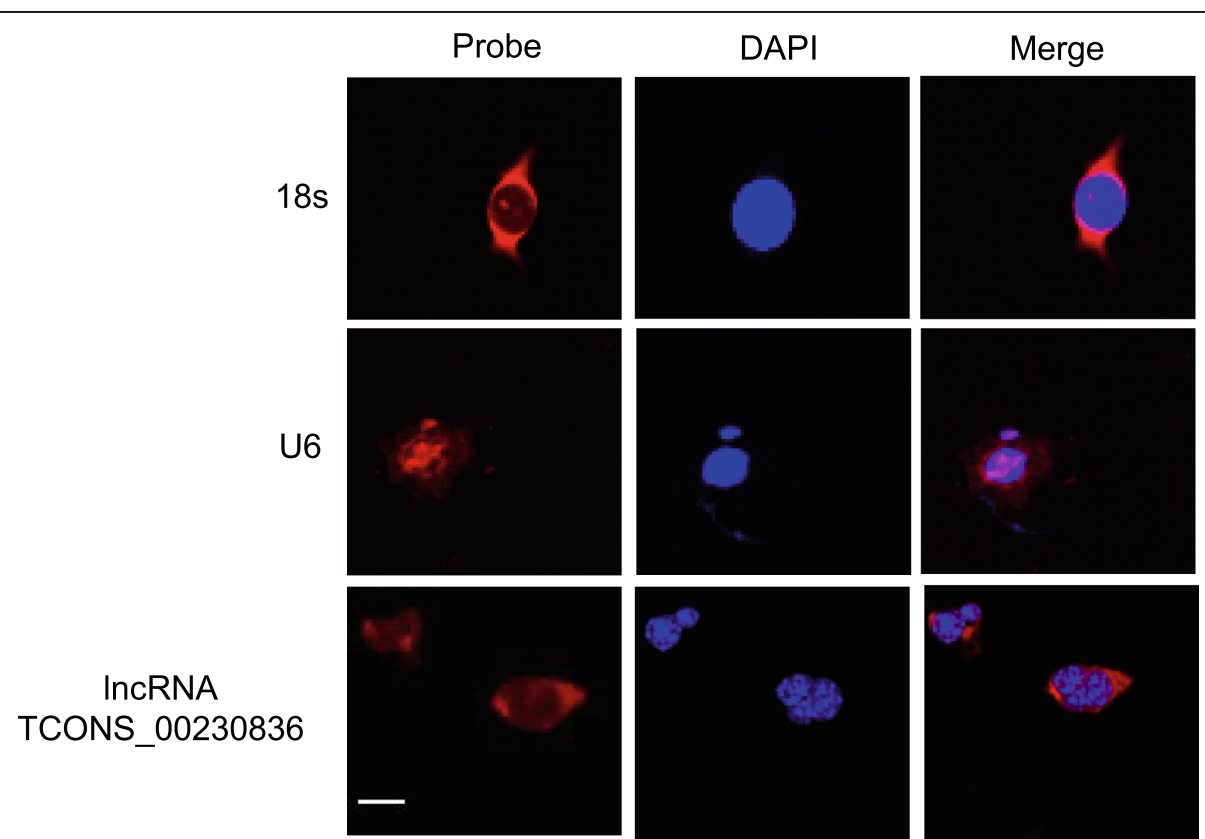

Fig. 3 Confocal images of FISH for localization of the IncRNA TCONS_00230836 (red) in $\beta$-TC6 cells. Nuclei were stained with DAPI (blue). 18S, probe for 185 rRNA, was used for cytoplasmic localization. U6, probe for U6 snRNA, was taken as a representative of nuclear localization. Scale bar, $10 \mu \mathrm{m}$ 


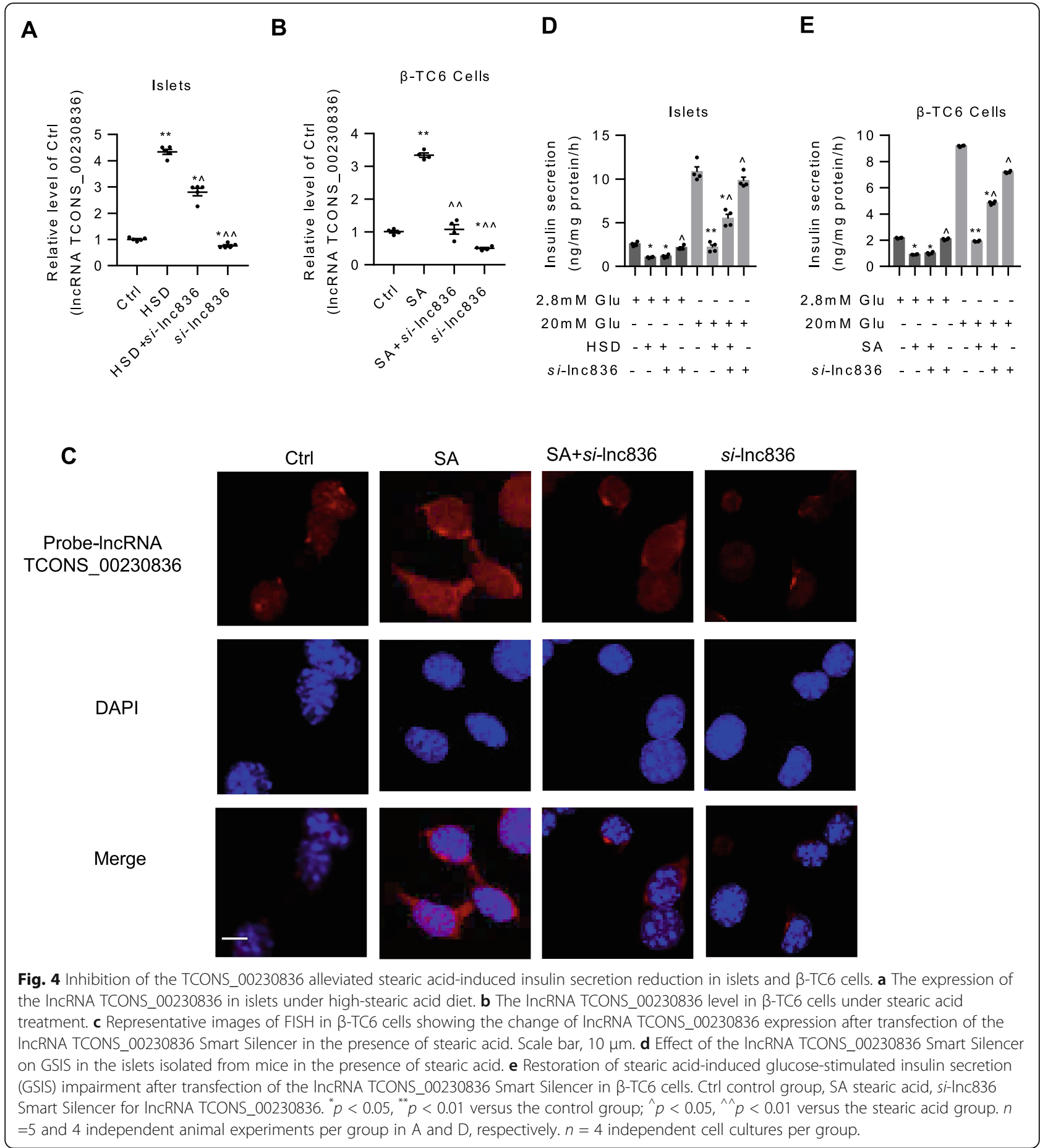

Effect of IncRNA TCONS_00230836 on the expressions of candidate ER stress-related mRNAs

In order to reveal the potential mRNAs targeted for lncRNA TCONS_00230836 in stearic acid-treated $\beta$ cell ER stress, the lncRNA TCONS_00230836-mRNAs co-expression network was constructed. Twelve upregulated mRNAs are positively associated with lncRNA TCONS_00230836 (Fig. 9a), and 15 downregulated mRNAs are negatively related to this
lncRNA (Fig. 9b). The $\log _{2}$ fold change of these upregulated and downregulated differentially expressed mRNAs were listed in Additional file 6. Among these mRNAs, six stearic acid-increased mRNA levels (positively related) (ENSMUST00000074898 [Hp], ENSMUST00000159720 [Alpk1], ENSMUST00000006956 [SAA3], ENSMUST00000086399 [Icam1], ENSMUST00000131456 [Serping1], and ENSMUST00000050785 [Lcn2]) were 
A

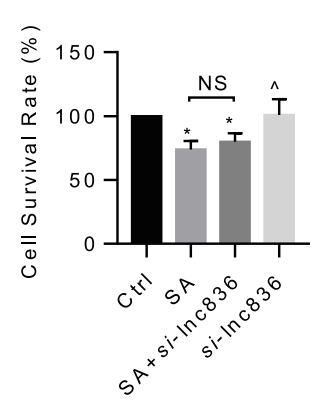

C
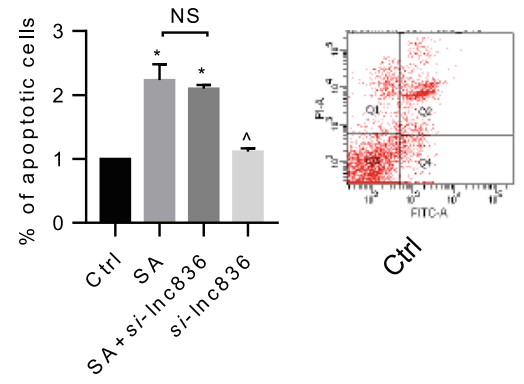

cit
B
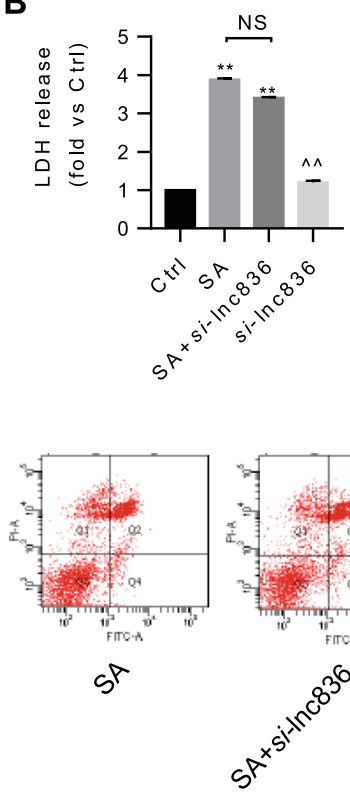
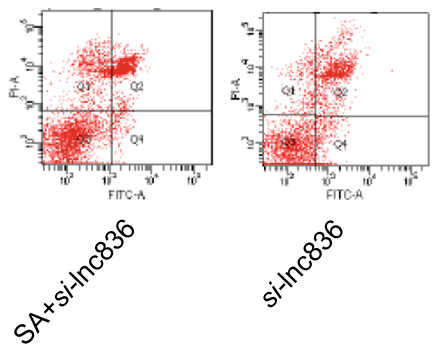
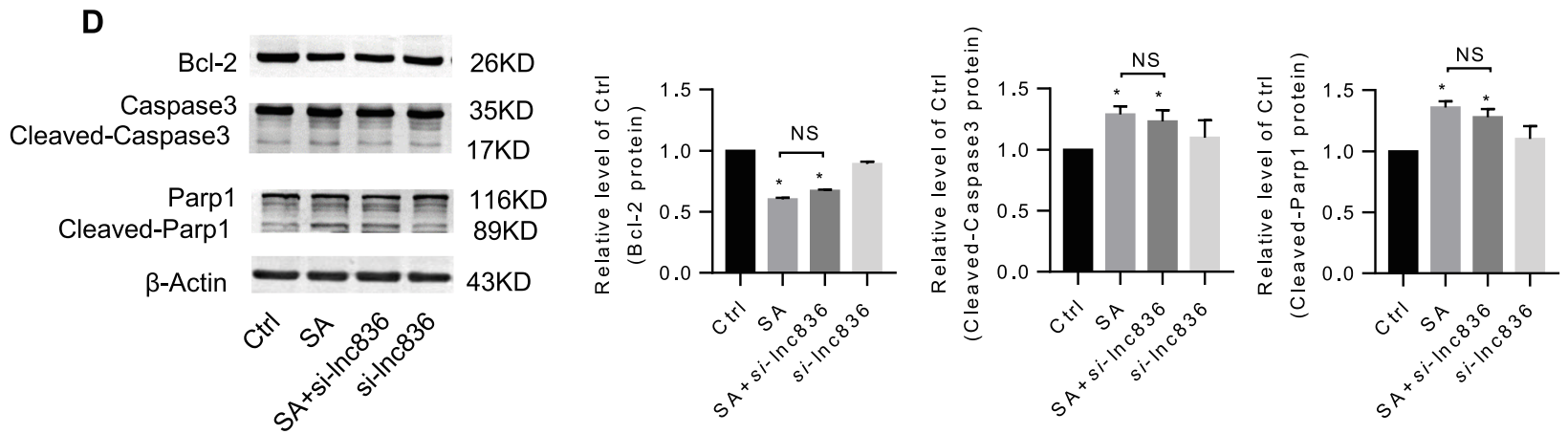

Fig. 5 The IncRNA TCONS_00230836 did not significantly reverse stearic acid-induced $\beta$-TC6 cell apoptosis. a, b Effect of the Smart Silencer for TCONS_00230836 on stearic acid-induced cell viability by CCK8 assay and cell death by LDH measurement, separately. $\mathbf{c}$ FCM revealed that the number of apoptotic cells was not altered after TCONS_00230836 inhibition under stearic acid treatment. d No significant changes in the expression of cleaved-caspase3, cleaved-Parp1, and Bcl-2 after inhibition of the IncRNA TCONS_00230836 by western blot analysis. NS not significant, SA stearic acid, si-Inc836 Smart Silencer for IncRNA TCONS_00230836. $n=3$ independent cell cultures per group. ${ }^{*} p<0.05,{ }^{* *} p<0.01$ versus the control group; ${ }^{\wedge} p<0.05,{ }^{\wedge} p<0.01$ versus the stearic acid group

effectively reversed by lncRNA TCONS_00230836 Smart Silencer, except ENSMUST00000006956 [SAA3]. Moreover, after transfection of lncRNA TCONS_00230836 Smart Silencer alone without stearic acid treatment, only Alpk1, Icam1, and Serping1 were significantly reduced (Fig. 9c). As for negatively related mRNAs, the expressions of six stearic acid-decreased mRNAs (ENSMUST00000124100 [Prn], ENSMUST00000092822 [Bcas3], ENSMUST00000021620 [Otub2], ENSMUST00000073388 [Afmid], ENSMUST00000149884 [Snapin], and ENSMUST00000185596 [Srgap2]) were markedly rescued after knocking down lncRNA TCONS_00230836, exept for snapin. Meanwhile, these six mRNAs were significantly upregulated after silencing lncRNA TCONS_00230836 in the absence of stearic acid (Fig. 9d).

\section{Discussion}

The prevalence of T2DM has been increasing worldwide, with an estimated 336 million people currently affected [24]. It is well established that exposing pancreatic $\beta$ cells to an elevated level of stearic acid causes their dysfunction, which is far advanced by the time diabetes is diagnosed clinically $[4-6,8]$. Therefore, the optimal management and prevention of T2DM should aim to ameliorate $\beta$ cell dysfunction at an early stage. However, the effective preventive targets are limited and still need to be comprehensively explored. The present study elucidated the pathophysiological role of lncRNA in stearic acid-treated $\beta$ cells. Our findings demonstrated that the IncRNA TCONS_00230836 was significantly increased in both stearic acid-induced $\beta$ - 


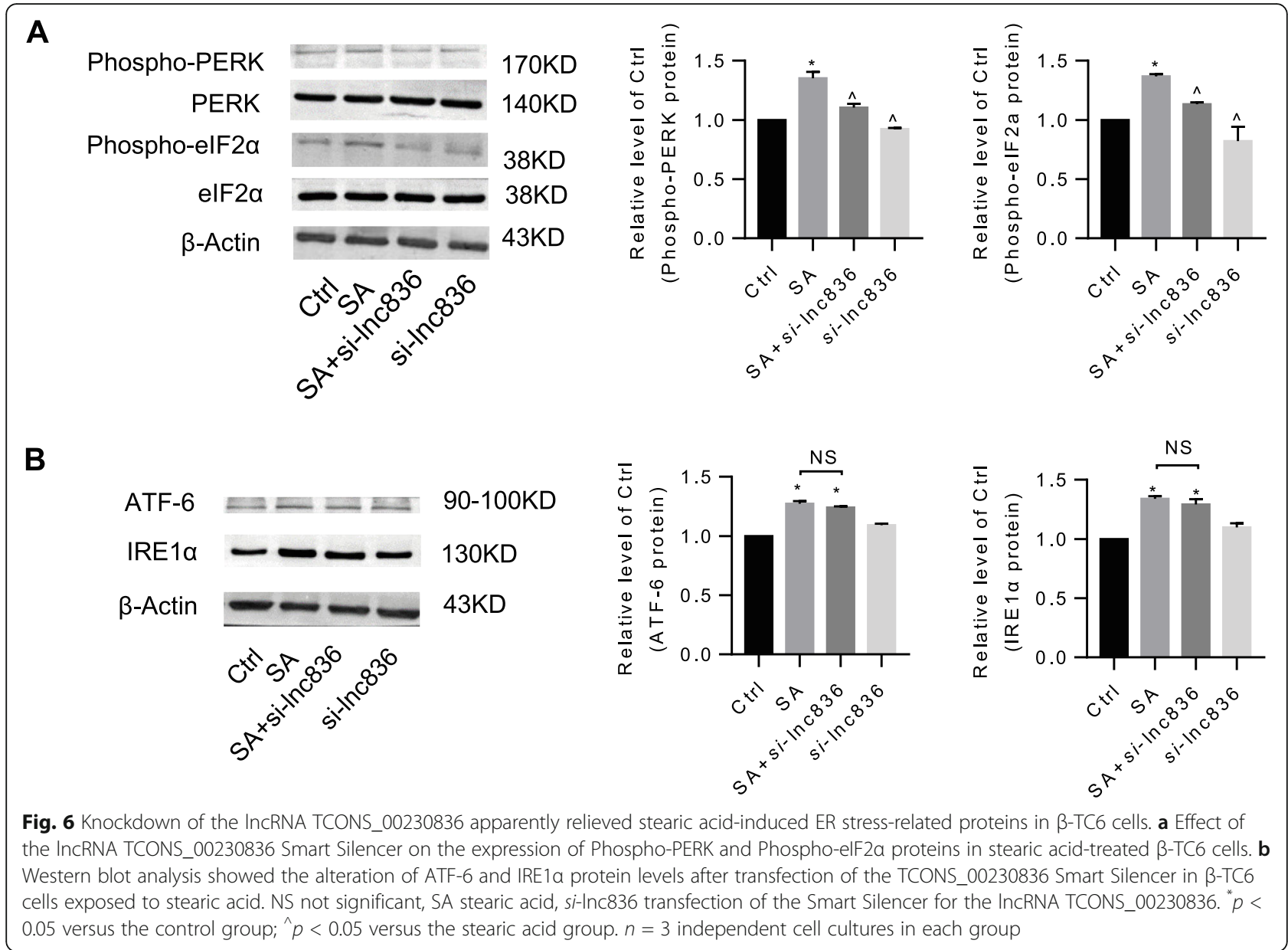

TC6 cells and the islets of mice fed a high-stearic-acid diet. Inhibition of the lncRNA TCONS_00230836 effectively protected against stearic acid-induced $\beta$ cell dysfunction. Interestingly, after knocking down the lncRNA TCONS_00230836, we found that stearic acidstimulated $\beta$ cell ER stress was apparently ameliorated via a PERK/eIF2 $\alpha$-dependent pathway, but no obvious improvement of stearic acid-induced apoptosis was observed.

Although a number of studies have preliminarily explored the mechanisms underlying stearic acid-induced pancreatic $\beta$ cell damage, the exact molecular targets and associated pathways still need to be established. Recently, accumulating evidence has suggested that noncoding RNAs play an important role in the $\beta$ cell injury caused by the long-term consumption of a high-fat diet, such as microRNAs [5, 8], circRNAs [25, 26], and lncRNAs [20, 27, 28]. Nevertheless, few studies have focused on the role of lncRNAs in $\beta$ cell dysfunction upon exposure to elevated levels of SFAs, especially stearic acid, on which no related research has previously been published. In our study, we used high-throughput sequencing and bioinformatic technology to select five
lncRNAs that were differentially expressed specifically in stearic acid-treated $\beta$-TC6 cells, compared with their levels in both control and palmitic acid groups (data not shown). Among the known lncRNAs, the lncRNA TCONS_00230836 displayed the largest fold increase, with an increase of $1.328 \log _{2}$ fold change in RNA sequencing results, 3.744-fold in stearic acid-induced $\beta$ TC6 cells, and 5.115-fold in islets of mice fed a highstearic-acid diet, as revealed by qRT-PCR.

It has been well clarified that lncRNAs have low sequence conservation and high tissue specificity [29]. Meanwhile, the expression of lncRNAs typically varies more between tissues than for other noncoding RNAs [30-32]. To investigate the difference of sequence conservation and differential expression of the lncRNA TCONS_00230836, we tested it in different tissues (islet, liver, skeletal muscle, brown adipose, peritesticular, and perirenal adipose tissues) which are closely related to T2DM. Our data indicated that there was a highly similar sequence of lncRNA TCONS_00230836 (similarity > $98 \%$ ) in the liver, brown adipose, and skeletal muscle, but not in peritesticular and perirenal adipose tissues, compared with that in islets. Moreover, the level of this 
A

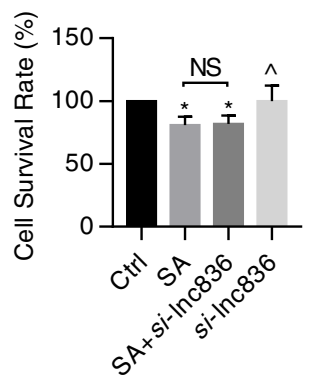

B

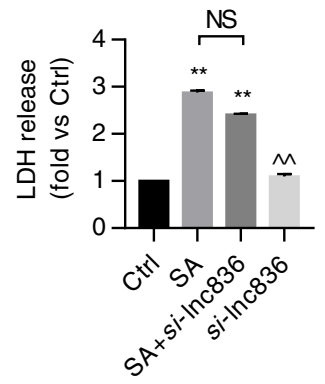

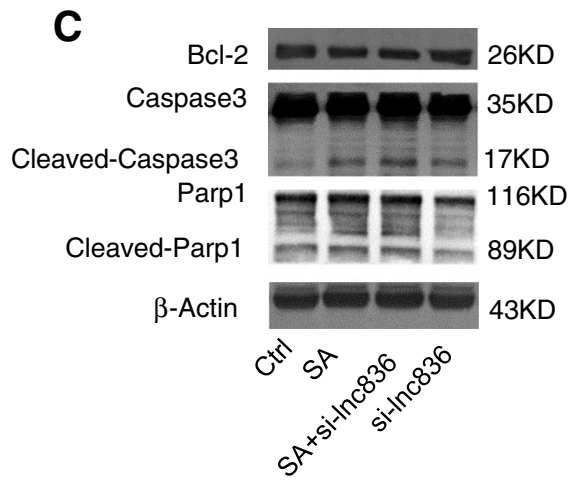

Fig. 7 Silencing InCRNA TCONS_00230836 did not markedly alter islet apoptosis exposure to stearic acid. a, b Assessment of cell viability in HSD mice islets treated with Smart Silencer for TCONS_00230836 by CCK8 assay and cell death by LDH measurement, separately. c Western blot analysis verifying the changes in the expression of cleaved-caspase3, cleaved-Parp1, and BCl-2 after inhibition of the IncRNA TCONS_00230836. NS not significant, SA stearic acid, si-Inc836 Smart Silencer for IncRNA TCONS_00230836. $n=5$ independent animal experiments per group. ${ }^{*} p<0.05$, ${ }^{* *} p<0.01$ versus the control group; ${ }^{\wedge} p<0.05,{ }^{\wedge} p<0.01$ versus the SA group
lncRNA was highest in the islets and lowest in the skeletal muscle of high-stearic-acid-fed mice, which suggested that this lncRNA may be specific to and enriched in the islets. This is the first key finding of our study.

To demonstrate the role of the IncRNA TCONS 00230836 in stearic acid-mediated lipotoxicity in $\beta$ cells, endogenous TCONS_00230836 in $\beta$-TC6 cells was abrogated by the application of its Smart Silencer, a highly effective inhibitor that specifically targets lncRNA TCONS_00230836 expressed in both the cytoplasm and the nucleus. We found that stearic acid-impaired GSIS was largely restored after silencing TCONS_00230836, which implied that a TCONS_00230836-mediated mechanism operated in the stearic acid-induced lipotoxicity of $\beta$ cells. However, how does the lncRNA TCONS_ 00230836 exert its influence and which process was improved in stearic acid-induced pancreatic $\beta$ cell injury?

ER stress and apoptosis are very important pathophysiological perturbations and are closely associated with $\beta$ cell lipotoxicity in the early stage of T2DM; they are not only independent of each other, but also have a close cause-effect relationship [33-37]. To reveal which process was affected by the IncRNA TCONS_00230836, we detected the alterations of ER stress and apoptosis induced by stearic acid after transfection of the Smart Silencer for the lncRNA TCONS_00230836. Our data indicated that transfection of the lncRNA TCONS 00230836 effectively ameliorated stearic acid-stimulated ER stress via a PERK/eIF2 $\alpha$-dependent pathway. As we know, ER stress can transduce apoptotic signals that may eventually result in apoptosis. However, unexpectedly, stearic acid-induced $\beta$ cell apoptosis was not significantly recovered after knocking down lncRNA TCONS_00230836 expression. Therefore, we speculate that there may be some other key regulatory factors involved in lncRNA TCONS_00230836-mediated $\beta$ cell ER stress. This is another important finding of our study.

In an effort to reveal the potential target for lncRNA TCONS_00230836 in stearic acid-induced ER stress, we analyzed the mRNAs profile by high-throughput screens in our previous study [38] and constructed the coexpression network between lncRNA TCONS_00230836 and targeted mRNAs which are closely related to ER stress. Then, the top six upregulated mRNAs and another top six downregulated mRNAs were selected for further identification. In the positive-relation group, qPCR results for the mRNA expressions indicated that Alpk1, Icam1, and Serping1 are probably involved in the 


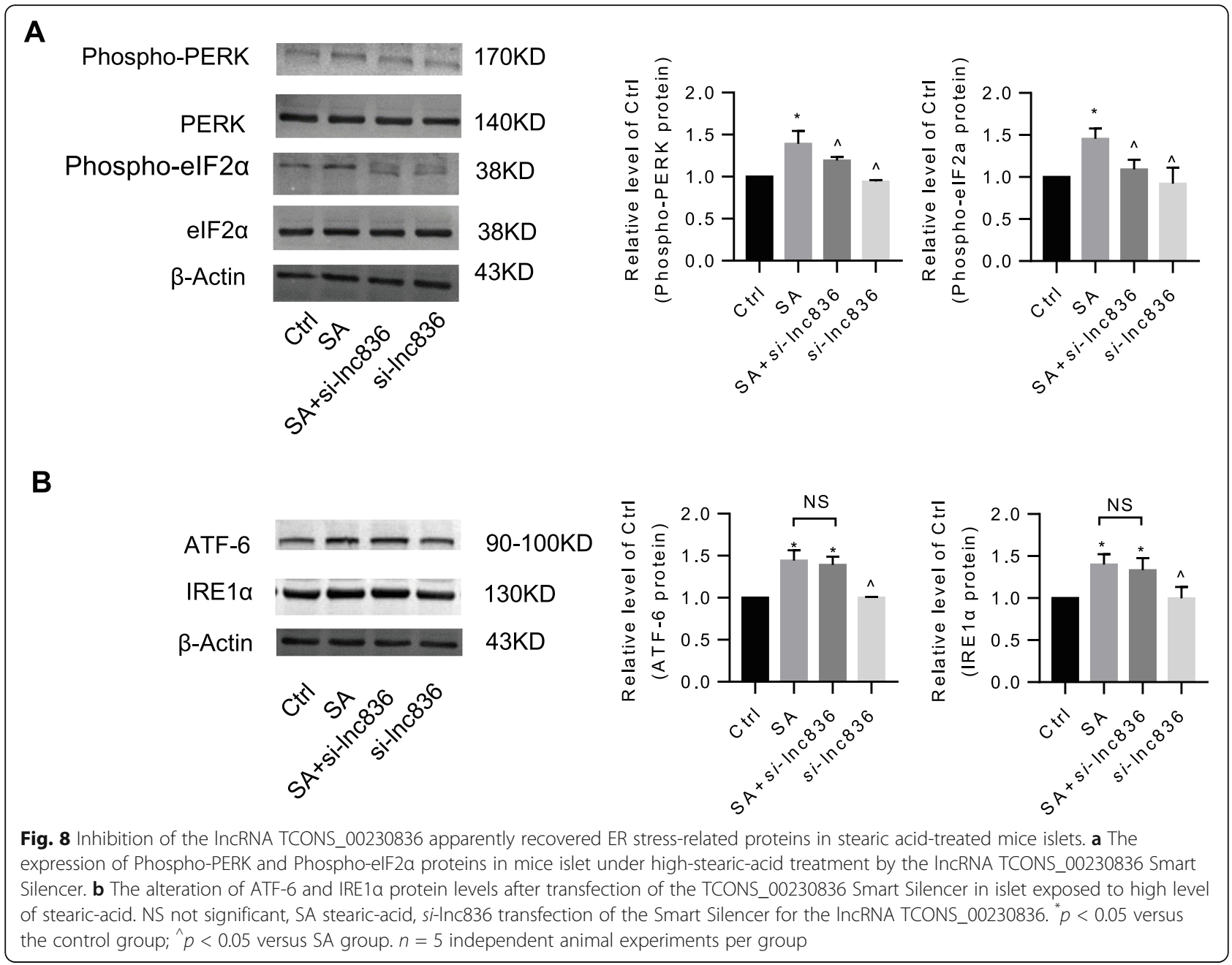

process of stearic acid-induced $\beta$ cell ER stress associated with lncRNA TCONS_00230836. While in negative-relation group, Prn, Bcas3, Otub2, Afmid, and Srgap 2 might play a critical role in stearic acid $\beta$ cell ER stress closely related to lncRNA TCONS_00230836. Among them, Afmid has been reported that they could lead to impaired glucose tolerance in type 2 diabetes [39]. Meanwhile, Otub2 has been shown to act through the inhibition of NF- $\mathrm{kB}$ signaling in type 1 diabetes [40, 41]. Further experiments should be performed to explore the precise regulatory relationship between these candidate mRNAs and lncRNA TCONS_00230836 as well as PERK/eIF2 $\alpha$-dependent signaling in stearic acid-treated $\beta$ cells.

Our understanding of lncRNAs in stearic acid-induced lipotoxicity to $\beta$ cells is still in its infancy and several questions remain unanswered. First, we did not assess the role of the IncRNA TCONS_00230836 in stearic acid-induced impairment of insulin secretion in an in vivo experiment. Second, we all know that lncRNAs exert their function through diverse regulatory mechanisms, for example, modulating translation, promoting mRNA degradation, or acting as miRNA sponges. In our previous study [5], we found that stearic acid-induced $\beta$ cell apoptosis is attributed to miR-34a$5 \mathrm{p}$, which is positively regulated by PERK/p53. While the present study indicated that inhibition of lncRNA TCONS_00230836 siginificantly reversed stearic acidincreased phosphor-PERK level. Therefore, further experiments still need to be performed to analyze the relationship and direct binding site between this lncRNA and miR-34a-5p, as well as other potential TCONS 00230836-related targets in stearic acid-induced $\beta$ cell dysfunction, which would improve our understanding of the regulatory mechanisms of the IncRNA TCONS 00230836 in stearic acid-induced lipotoxicity to pancreatic $\beta$ cells.

\section{Values}

We provide evidence that stearic acid can stimulate upregulation of the lncRNA TCONS_00230836 in stearic acid-treated pancreatic $\beta$ cells. It appears that this 


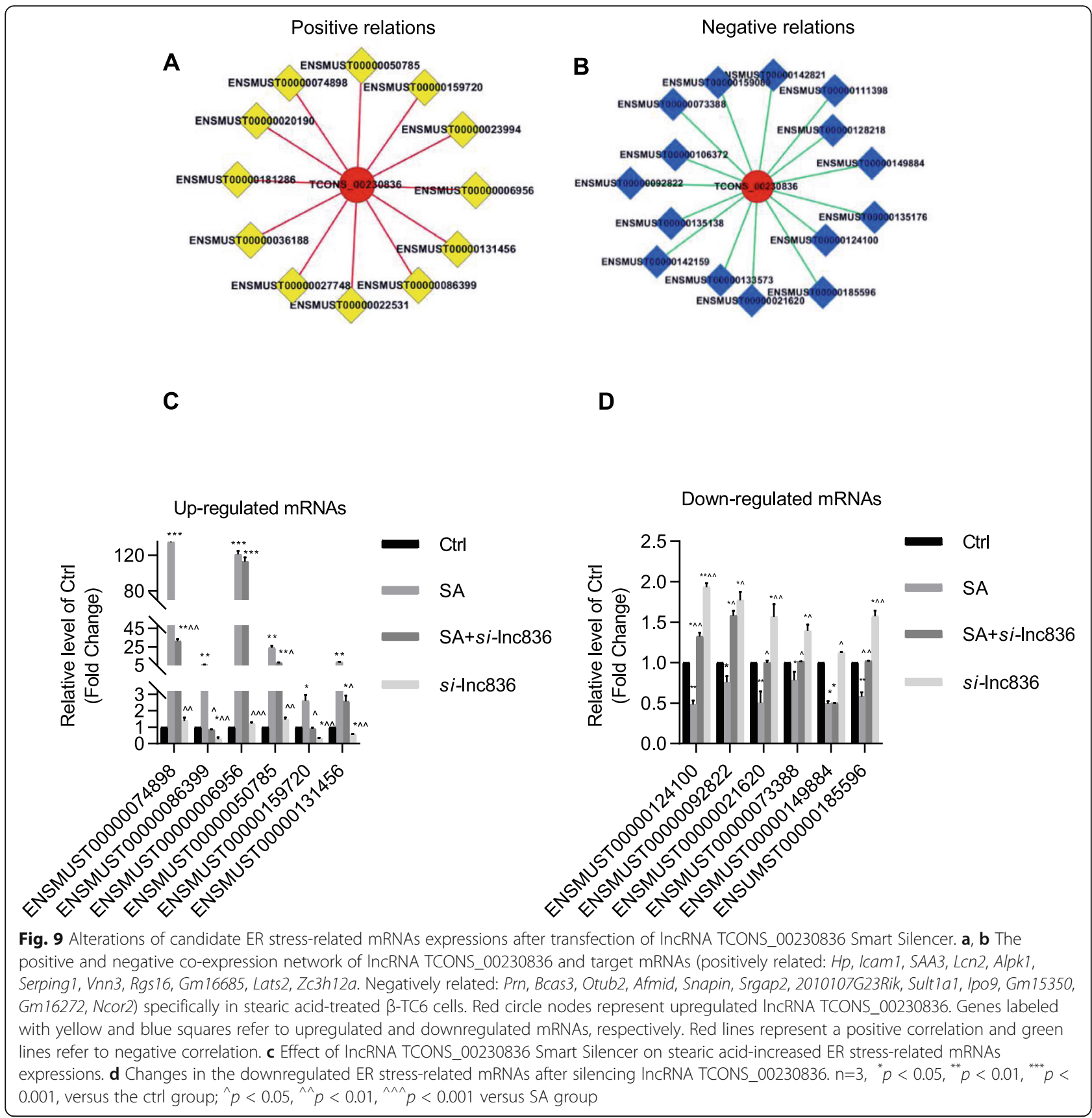

IncRNA is specific to and enriched in pancreatic $\beta$ cells. Suppression of this lncRNA could effectively restore stearic acid-induced impairment of insulin secretion through the amelioration of ER stress rather than apoptosis. Among the three major ER-stress-related sensors, only PERK/eIF2 $\alpha$ contributes to this process after knockdown of lncRNA TCONS_00230836. These findings provide novel insight into stearic acid-induced lipotoxicity and the progression of T2DM, whereby lowering the level of the lncRNA TCONS_00230836 might be an effective strategy for improving lipotoxicity in $\beta$ cells.
Abbreviations

CCK8: Cell Counting Kit 8; GSIS: Glucose-stimulated insulin secretion; HSD: High stearic acid diet; LDH: Lactate dehydrogenase; PA: Palmitic acid; qRT-PCR: Quantitative real-time PCR; SA: Stearic acid; SFAs: Saturated fatty acids; T2DM: Type 2 diabetes mellitus

\section{Supplementary Information}

The online version contains supplementary material available at https://doi. org/10.1186/s12263-021-00685-5.

Additional file 1. The composition of the diet for mice 
Additional file 2. The composition of fasting serum NEFAs profile in normal and HSD mice at 20

Additional file 3. Body weight and serum analysis in normal and HSD mice at 20 weeks.

Additional file 4. Alteration of the IncRNA TCONS 00230836 level in brown adipose, liver, and skeletal muscle of mice fed a high-stearic-acid diet. $n=5$ mice per group. Ctrl, control group; HSD, high-stearic-acid diet. ${ }^{*} P<0.05,{ }^{* *} P<0.01$ versus the Ctrl group.

Additional file 5. The intracellular insulin content in $\beta$-TC6 cells after transfection of the TCONS_00230836 Smart Silencer in the absence or presence of stearic acid. $n=3$ cell cultures per group. Ctrl, control group; SA, stearic acid, si-Inc836, Smart Silencer for TCONS_00230836.

Additional file 6 . The $\log _{2}$ fold change of up- and down-regulated differentially expressed mRNAs related to IncRNA TCONS_00230836 (PCC $\geq 0.950$, or $P C C \leq-0.950, P<0.05$ ) in stearic acid-induced $\beta$-TC6 cells by high-throughput RNA-sequencing.

\section{Acknowledgements}

\section{Not applicable.}

\section{Authors' contributions}

H.L. and C.S. conceived and designed the experiments. R.G., Y.Z., Y.Y., S.S., and Q.Z. performed the experiments. R.G. analyzed data. H.L. and R.G. wrote the manuscript. H.L., R.G., S.L., and X.C. reviewed and edited the manuscript. We thank Liwen Bianji, Edanz Group China (www.liwenbianji.cn/ac), for editing the English text of a draft of this manuscript.

\section{Funding}

This work was supported by the Excellent Youth Foundation of Heilongjiang Province of China (YQ2020H033), University Nursing Program for Young Scholars with Creative Talents in Heilongjiang Province (UNPYSCT-201705), and National Natural Science Foundation of China (No. 81773424).

\section{Availability of data and materials}

All of the data are available with reasonable request from the corresponding authors.

\section{Ethics approval and consent to participate}

All animal procedures were ethically approved by the Institutional Animal Care and Use Committee of Harbin Medical University, and the animals were maintained in line with the guidelines of the Animal Experimental Center of Harbin Medical University.

\section{Consent for publication}

Not applicable.

\section{Competing interests}

The authors declare that they have no comepeting interests.

Received: 3 September 2020 Accepted: 19 March 2021

Published online: 22 May 2021

\section{References}

1. Palomer X, Pizarro-Delgado J, Barroso E, Vazquez-Carrera M. palmitic and oleic acid: the Yin and Yang of fatty acids in type 2 diabetes mellitus. Trends Endocrinol Metab. 2018;29(3):178-90. https://doi.org/10.1016/j.tem.2 017.11.009.

2. Hilvo M, Salonurmi T, Havulinna AS, Kauhanen D, Pedersen ER, Tell GS, et al. Ceramide stearic to palmitic acid ratio predicts incident diabetes. Diabetologia. 2018;61(6):1424-34. https://doi.org/10.1007/s00125-018-4590-6.

3. Zhou T, Wang G, Lyu Ym, Wang L, Zuo S, Zou J, Sun L, Zhao W, Shu C, Yang YG, Hu Z Upregulation of SLAMF3 on human T cells is induced by palmitic acid through the STAT5-PI3K/Akt pathway and features the chronic inflammatory profiles of type 2 diabetes. Cell Death Dis. 2019;10: 559, 8, DOI: https://doi.org/10.1038/s41419-019-1791-y

4. Chu X, Liu L, Na L, Lu H, Li S, Li Y, et al. Sterol regulatory element-binding protein-1c mediates increase of postprandial stearic acid, a potential target for improving insulin resistance, in hyperlipidemia. Diabetes. 2013;62(2):56171. https://doi.org/10.2337/db12-0139.
5. Lu H, Hao L, Li S, Lin S, Lv L, Chen Y, et al. Elevated circulating stearic acid leads to a major lipotoxic effect on mouse pancreatic beta cells in hyperlipidaemia via a miR-34a-5p-mediated PERK/p53-dependent pathway. Diabetologia. 2016;59(6):1247-57. https://doi.org/10.1007/s00125-016-3900-0.

6. Zhao L, Ni Y, Yu H, Zhang P, Zhao A, Bao Y, et al. Serum stearic acid/ palmitic acid ratio as a potential predictor of diabetes remission after RouXen-Y gastric bypass in obesity. FASEB J. 2017;31(4):1449-60. https://doi.org/1 0.1096/fj.201600927R.

7. Liu L, Li Y, Guan C, et al. Free fatty acid metabolic profile and biomarkers of isolated post-challenge diabetes and type 2 diabetes mellitus based on GCMS and multivariate statistical analysis. J Chromatogr B Analyt Technol Biomed Life Sci. 2010;878:2817-25.

8. Guo R, Yu Y, Zhang YM, Li Y, Chu X, Lu H, et al. Overexpression of miR$297 b-5 p$ protects against stearic acid-induced pancreatic beta-cell apoptosis by targeting LATS2. Am J Physiol Endocrinol Metab. 2020;318(3):E430-9. https://doi.org/10.1152/ajpendo.00302.2019.

9. Nemcova-Furstova V, Balusikova K, Sramek J, James RF, Kovar J. Caspase-2 and JNK activated by saturated fatty acids are not involved in apoptosis induction but modulate ER stress in human pancreatic beta-cells. Cell Physiol Biochem. 2013;31(2-3):277-89. https://doi.org/10.1159/000343367.

10. Nemcova-Furstova V, Balusikova K, Halada P, Pavlikova N, Sramek J, Kovar J. Stearate-induced apoptosis in human pancreatic beta-cells is associated with changes in membrane protein expression and these changes are inhibited by oleate. Proteomics Clin Appl. 2019;13: e1800104.

11. Sarropoulos I, Marin R, Cardoso-Moreira M, Kaessmann H. Developmental dynamics of IncRNAs across mammalian organs and species. Nature. 2019; 571(7766):510-4. https://doi.org/10.1038/s41586-019-1341-x.

12. Ferre F, Colantoni A, Helmer-Citterich M. Revealing protein-IncRNA interaction. Brief Bioinform. 2016;17(1):106-16. https://doi.org/10.1093/bib/bbv031.

13. Zhang $X$, Wang W, Zhu W, Dong J, Cheng Y, Yin Z, et al. Mechanisms and functions of long non-coding RNAs at multiple regulatory levels. Int J Mol Sci. 2019;20(22). https://doi.org/10.3390/ijms20225573.

14. Jin F, Wang N, Zhu Y, You L, Wang L, de W, et al. Downregulation of long noncoding RNA Gas5 affects cell cycle and insulin secretion in mouse pancreatic beta cells. Cell Physiol Biochem. 2017:43(5):2062-73. https://doi. org/10.1159/000484191.

15. Bai X, Geng J, Li X, Wan J, Liu J, Zhou Z, et al. Long noncoding RNA LINC01619 regulates microRNA-27a/forkhead box protein 01 and endoplasmic reticulum stress-mediated podocyte injury in diabetic nephropathy. Antioxid Redox Signal. 2018;29(4):355-76. https://doi.org/10.1 089/ars.2017.7278

16. Zhang Q, Wang J, Li H, et al. LnCRNA Gm12664-001 ameliorates nonalcoholic fatty liver through modulating miR-295-5p and CAV1 expression. Nutr Metab (Lond). 2020;17:13.

17. Muret $K$, Desert $C$, Lagoutte $L$, et al. Long noncoding RNAs in lipid metabolism: literature review and conservation analysis across species. BMC Genomics. 2019;20(1):882. https://doi.org/10.1186/s12864-019-6093-3.

18. Degirmenci U, Li J, Lim YC, Siang DTC, Lin S, Liang H, et al. Silencing an insulin-induced IncRNA, LnCASIR, impairs the transcriptional response to insulin signalling in adipocytes. Sci Rep. 2019;9(1):5608. https://doi.org/10.1 038/s41598-019-42162-5.

19. Han M, You L, Wu Y, Gu N, Wang Y, Feng $X$, et al. RNA-sequencing analysis reveals the potential contribution of IncRNAs in palmitic acid-induced insulin resistance of skeletal muscle cells. Biosci Rep. 2020;40(1). https://doi. org/10.1042/BSR20192523

20. Kong $X$, Liu CX, Wang GD, et al. LnCRNA LEGLTBC functions as a ceRNA to antagonize the effects of miR-34a on the downregulation of SIRT1 in glucolipotoxicity-induced INS-1 beta cell oxidative stress and apoptosis. Oxid Med Cell Longev. 2019;2019:4010764.

21. Arnes L, Akerman I, Balderes DA, Ferrer J, Sussel L. betalinc1 encodes a long noncoding RNA that regulates islet beta-cell formation and function. Genes Dev. 2016:30(5):502-7. https://doi.org/10.1101/gad.273821.115.

22. Goldstein JL, Basu SK, Brown MS. Receptor-mediated endocytosis of lowdensity lipoprotein in cultured cells. Methods Enzymol. 1983;98:241-60. https://doi.org/10.1016/0076-6879(83)98152-1.

23. Guo F, Huang C, Liao X, et al. Beneficial effects of mangiferin on hyperlipidemia in high-fat-fed hamsters. Mol Nutr Food Res. 2011;55: 1809-18.

24. Ashcroft FM, Rorsman P. Diabetes mellitus and the beta cell: the last ten years. Cell. 2012;148(6):1160-71. https://doi.org/10.1016/j.cell.2012.02.010. 
25. Stoll L, Sobel J, Rodriguez-Trejo A, Guay C, Lee K, Venø MT, et al. Circular RNAs as novel regulators of beta-cell functions in normal and disease conditions. Mol Metab. 2018;9:69-83. https://doi.org/10.1016/j.molmet.2018.01.010.

26. Bai C, Yang W, Lu Y, Wei W, Li Z, Zhang L. Identification of circular RNAs regulating islet beta-cell autophagy in type 2 diabetes mellitus. Biomed Res Int. 2019;2019:4128315.

27. Ruan Y, Lin N, Ma Q, Chen R, Zhang Z, Wen W, et al. Circulating LncRNAs analysis in patients with type 2 diabetes reveals novel genes influencing glucose metabolism and islet beta-cell function. Cell Physiol Biochem. 2018; 46(1):335-50. https://doi.org/10.1159/000488434.

28. Knoll M, Lodish HF, Sun L. Long non-coding RNAs as regulators of the endocrine system. Nat Rev Endocrinol. 2015;11(3):151-60. https://doi.org/1 0.1038/nrendo.2014.229.

29. Nagano T, Fraser P. No-nonsense functions for long noncoding RNAs. Cell. 2011;145(2):178-81. https://doi.org/10.1016/j.cell.2011.03.014.

30. Cabili MN, Trapnell C, Goff L, Koziol M, Tazon-Vega B, Regev A, et al. Integrative annotation of human large intergenic noncoding RNAs reveals global properties and specific subclasses. Genes Dev. 2011;25(18):1915-27. https://doi.org/10.1101/gad.17446611.

31. Derrien T, Johnson R, Bussotti G, Tanzer A, Djebali S, Tilgner H, et al. The GENCODE $\mathrm{V} 7$ catalog of human long noncoding RNAs: analysis of their gene structure, evolution, and expression. Genome Res. 2012;22(9):1775-89. https://doi.org/10.1101/gr.132159.111.

32. Pauli A, Valen E, Lin MF, Garber M, Vastenhouw NL, Levin JZ, et al. Systematic identification of long noncoding RNAs expressed during zebrafish embryogenesis. Genome Res. 2012;22(3):577-91. https://doi.org/1 0.1101/gr.133009.111.

33. Vong CT, Tseng HHL, Kwan YW, Lee SM, Hoi MPM. Novel protective effect of O-1602 and abnormal cannabidiol, GPR55 agonists, on ER stress-induced apoptosis in pancreatic beta-cells. Biomed Pharmacother. 2019;111:1176-86. https://doi.org/10.1016/j.biopha.2018.12.126.

34. Ljubkovic M, Gressette M, Bulat C, Cavar M, Bakovic D, Fabijanic D, et al. Disturbed fatty acid oxidation, endoplasmic reticulum stress, and apoptosis in left ventricle of patients with type 2 diabetes. Diabetes. 2019;68(10):192433. https://doi.org/10.2337/db19-0423.

35. Kharroubi I, Ladriere L, Cardozo AK, Dogusan Z, Cnop M, Eizirik DL. Free fatty acids and cytokines induce pancreatic beta-cell apoptosis by different mechanisms: role of nuclear factor-kappaB and endoplasmic reticulum stress. Endocrinology. 2004;145(11):5087-96. https://doi.org/10.1210/en.20040478.

36. Wang J, Yang $X$, Zhang J. Bridges between mitochondrial oxidative stress, ER stress and mTOR signaling in pancreatic beta cells. Cell Signal. 2016;28(8): 1099-104. https://doi.org/10.1016/j.cellsig.2016.05.007.

37. Tomita T. Apoptosis in pancreatic beta-islet cells in Type 2 diabetes. Bosn J Basic Med Sci. 2016;16(3):162-79. https://doi.org/10.17305/bjbms.2016.919.

38. Yu Y, Guo R, Zhang Y, et al. miRNA-mRNA profile and regulatory network in stearic acid-treated beta-cell dysfunction. J Endocrinol. 2020;246:13-27.

39. Hugill AJ, Stewart ME, Yon MA, Probert F, Cox IJ, Hough TA, et al. Loss of arylformamidase with reduced thymidine kinase expression leads to impaired glucose tolerance. Biol Open. 2015;4(11):1367-75. https://doi.org/1 $0.1242 /$ bio. 013342

40. Ma Y, Sun Y. miR-29a-3p inhibits growth, proliferation, and invasion of papillary thyroid carcinoma by suppressing NF-kappaB signaling via direct targeting of OTUB2. Cancer Manag Res. 2019;11:13-23.

41. Beck A, Vinik Y, Shatz-Azoulay H, Isaac R, Streim S, Jona G, et al. Otubain 2 is a novel promoter of beta cell survival as revealed by siRNA highthroughput screens of human pancreatic islets. Diabetologia. 2013;56(6): 1317-26. https://doi.org/10.1007/s00125-013-2889-x.

\section{Publisher's Note}

Springer Nature remains neutral with regard to jurisdictional claims in published maps and institutional affiliations.

Ready to submit your research? Choose BMC and benefit from:

- fast, convenient online submission

- thorough peer review by experienced researchers in your field

- rapid publication on acceptance

- support for research data, including large and complex data types

- gold Open Access which fosters wider collaboration and increased citations

- maximum visibility for your research: over $100 \mathrm{M}$ website views per year

At $\mathrm{BMC}$, research is always in progress.

Learn more biomedcentral.com/submissions 